\title{
EFFECT OF GARLIC POWDER ON GROWTH PERFORMANCE AND BLOOD METABOLITES IN MALE LAMBS
}

\author{
Ahmad Bazyar", Nour Mohamad Torbatinejad, Maria Amini, Mojtaba Ahani Azari \\ Gorgan University of Agricultural Sciences and Natural Resources, Animal Science Faculty, \\ Department of Livestock and Poultry Feed, Gorgan, Iran; \\ *Corresponding Author Ahmad Bazyar, e-mail: bazyar@aftermail.ir;
}

Received January 2020; Accepted March 2020; Published April 2020;

DOI: https://doi.org/10.31407/ijees10.213

\begin{abstract}
This study was conducted to evaluate the effect of different levels of garlic powder (GP) on growth performance and blood metabolites of male lambs. Twenty male lambs of Dalagh breed with 6 months of age and mean initial body weight of $31.5 \pm 2.5 \mathrm{~kg}$ in a 91-days ( 7 days for adaptation and 84 days trial) were assigned randomly to four dietary treatments with five replicates per treatment in a completely randomized design. Treatment were include: control (without GP), 5, 10 and $15 \mathrm{gr}$ GP/lamb/day. The lambs were fed individually ad libitum. The blood samples were collected in weeks $0,4,8,12$ and lambs were weighed every two weeks. Dry matter intake (DMI) was determined every two weeks. The results of these experiments showed that dry matter intake of lambs fed with 15 grams GP per day increased compared with control. Adding GP had no significant effect on the average daily gain (ADG) and feed conversion ratio (FCR). The GP had no effect on serum blood glucose, urea and triglyceride concentration, but treatment with high garlic powder decreased blood urea and triglyceride numerically. In conclusion, the results of these experiments showed that dry matter intake of lambs fed with 15 grams GP per day increased compared with control, but they had no change in fattening performance and blood metabolites of male Dalagh lambs.
\end{abstract}

Key words: Lambs, garlic powder, growth performance, blood metabolites 